\title{
Changes in Protein Profiles of Bean Leaves Infected by Bean Golden Mosaic Virus
}

\author{
Yasunori KogA-BAN ${ }^{* * *}$, Masanori SAKANISHI* and Masato IKEGAMI*
}

\begin{abstract}
The changes in protein profiles of bean leaves (Phaseolus vulgaris) during the infection process of geminivirus, bean golden mosaic virus (BGMV), were studied using one- and two-dimensional polyacrylamide gel electrophoresis. After Coomassie Blue staining, no differences between BGMV-and mock-infected plants were observed in either one- or two-dimensional gel profiles. However, comparison of the protein profiles after incorporation of $\left.{ }^{[35} \mathrm{S}\right]$ methionine showed that two specific polypeptides were induced by virus infection. One was the coat protein of BGMV and the other was a $24 \mathrm{kDa}$ protein assumed to be expressed by the host plant genome. During the progress of viral infection, the virus coat protein was strongly expressed at the late stage, while the $24 \mathrm{kDa}$ protein was expressed mainly at the early stage of infection. We suggest that this $24 \mathrm{kDa}$ protein plays an important role in BGMV infection.
\end{abstract}

(Received August 13, 1991)

Key words : geminivirus, Phaseolus vulgaris, virus infection, virus-induced protein, PAGE.

\section{INTRODUCTION}

Bean golden mosaic virus (BGMV) is a whitefly-borne disease agent that belongs to the geminivirus group, whose members are characterized by geminate virions and circular single-stranded DNA genomes ${ }^{2,15}$. The genome of BGMV was found to be composed of two single-stranded circular DNAs of similar size, approximately $2.6 \mathrm{~kb}^{7,8,12)}$. The complete DNA sequence of the BGMV genome has also been determined ${ }^{11,19)}$.

The cloned DNAs of BGMV were able to infect the bean plant, Phaseolus vulgaris ${ }^{1820)}$. We previously identified the coat protein gene of BGMV on DNA $1^{21}$. The function essential for systemic spread and symptom development is encoded by DNA 2 (Aosaki and Ikegami in preparation), as also found in a similar geminivirus, tomato golden mosaic virus ${ }^{24)}$. The functions of the tomato golden mosaic virus gene products are now being extensively studied using transgenic plants ${ }^{9,10)}$.

Generally, virus infection does not seem to be carried out by the virus products alone, but may progress through a series of interactions between the virus and host plant. Therefore, it is possible that each virus requires a specific cellular environment, together with certain gene products, from the host plant. For example, in the case of tobacco mosaic virus (TMV) it is known that the type of symptom, i.e. systemic mosaic or necrotic local lesions, is controlled by a combination of host and viral genes ${ }^{17)}$. Furthermore, the synthesis of pathogen-related proteins (defined as extracellular plant polypeptides), is induced in the process of TMV infection which causes hypersensitive response ${ }^{1,27,28}$. The physiological role of these infection-induced polypeptides is not clear. However, we think that characterization of the changes in protein profile of the host plant after virus infection could reveal some part of the interaction

* NODAI Research Institute, Tokyo University of Agriculture, Setagaya-ku, Tokyo 156, Japan 東京農業大学 総合研究所

** Present address: National Institute of Agrobiological Resources, Tsukuba Science City, Ibaraki 305, Japan 現在：農林水産省農業生物資源研究所 
process between virus and host plant, and allow identification of proteins which play an important role on virus infection.

In this study, we have analyzed the differences in protein profiles of host plant bean trifoliolate leaves after systemic BGMV infection using one- and two-dimensional polyacrylamide gel electrophoresis (PAGE).

\section{MATERIALS AND METHODS}

Plant materials. BGMV-infected plants were obtained by inoculating the expanding primary leaves of a nine-day-old bean plants (Phaseolus vulgaris L. cv. "Top Crop"). Mock-infected plants were obtained by mechanical stress of inoculation without virus. Plants were grown in a biotron (Koito Ltd.) with a day/night temperature of $30^{\circ} / 25^{\circ} \mathrm{C}$ and a day length of $14 \mathrm{hr}\left(80 \mu \mathrm{Em}^{-2} \mathrm{~s}^{-1}\right)$ at $80 \%$ humidity, and systemically infected trifoliolate leaves were used for protein extraction.

Protein radiolabeling and extraction. Leaf proteins of the BGMV-infected bean plant were labeled with $\left[{ }^{35} \mathrm{~S}\right]$ methionine according to the method of Guy et al. $\left.{ }^{5}{ }^{\left[{ }^{35} \mathrm{~S}\right.}\right]$ methionine $(1,055 \mathrm{Ci} / \mathrm{mmol}$, New England Nuclear) was diluted with $0.01 \%(\mathrm{v} / \mathrm{v})$ Triton X-100 to a concentration of $1 \mu \mathrm{Ci} / \mu \mathrm{l}$. A 10 $\mu 1$ aliquot of the radiolabel solution was applied to the underside (abaxial surface) of one leaf and the plant was then incubated for $6 \mathrm{hr}$ at $30^{\circ} \mathrm{C}$. The labeled part of the leaf was then detached and used for protein extraction ${ }^{6}$. Leaf tissue $(100 \mathrm{mg}$ ) was homogenized in mortar with $1 \mathrm{ml}$ of $80 \% \mathrm{v} / \mathrm{v}$ phenol containing $50 \mathrm{mM}$ EDTA, $100 \mathrm{mM} \mathrm{KCl}, 1 \mathrm{mM}$ phenylmethylsulfonyl fluoride, and $2 \% \mathrm{v} / \mathrm{v} 2$ mercaptoethanol buffered with $120 \mathrm{mM}$ Tris- $\mathrm{HCl}$ (pH 6.8). The phenol extract was vigorously mixed and partitioned three times with $1 \mathrm{ml}$ of the buffer solution to remove nucleic acids and other aqueous soluble materials. Phenol-phase-insoluble cell debris was removed by centrifugation at $15,000 \mathrm{~g}$ for 10 min. Proteins were precipitated from the phenol following the addition of 5 volumes of $100 \mathrm{mM}$ ammonium acetate, $1 \% \mathrm{v} / \mathrm{v} 2$-mercaptoethanol in methanol $\left(-20^{\circ} \mathrm{C}\right)$ for $2 \mathrm{hr}$ at $-80^{\circ} \mathrm{C}$. Following centrifugation at $15,000 \mathrm{~g}$ for $5 \mathrm{~min}$, the pellet was washed once with $1 \mathrm{ml}$ of the ammonium acetate solution and twice with $1 \mathrm{ml}$ of acetone containing $1 \%(\mathrm{v} / \mathrm{v}) 2$-mercaptoethanol. The white protein pellet was briefly air-dried, and then dissolved in $100 \mu \mathrm{l}$ of O'Farrell lysis buffer containing $9.5 \mathrm{M}$ urea, 2\% $(\mathrm{w} / \mathrm{v}) \mathrm{NP}-40,2 \%$ Ampholine and 5\% 2-mercaptoethanol ${ }^{22}$. The protein content was determined by the Lowry method ${ }^{16)}$, and the extracts were stored at $-80^{\circ} \mathrm{C}$. The amount of incorporated $\left[{ }^{35} \mathrm{~S}\right]$ methionine was measured by a liquid scintillation counter.

Gel electrophoresis. For one-dimensional PAGE, the gels and buffer solutions were prepared as described by Laemmli ${ }^{14)}$ and samples containing $50 \mu \mathrm{g}$ protein were separated by PAGE and stained with Coomassie Blue R-250. For autoradiograms, labeled proteins $\left(1 \times 10^{4} \mathrm{cpm}\right)$ were applied to the gels and exposed for eight weeks at room temperature. Two-dimensional PAGE was performed according to O'Farrell ${ }^{22)}$ and O'Farrell et al. ${ }^{23)}$ Proteins were dissolved in lysis buffer prepared by mixing a $0.5 \%$ Ampholine ( $\mathrm{pH} \mathrm{5-7)} \mathrm{(Pharmacia,} \mathrm{LKB)} \mathrm{with} \mathrm{a} \mathrm{1.5 \%} \mathrm{Ampholine} \mathrm{(} \mathrm{pH} 3.5-10)$. In each experiment, $1 \times 10^{5}$ $\mathrm{cpm}$ of TCA-insoluble radioactivity was loaded onto each isoelectric focusing gel. Focussed gels were equilibrated in equilibration buffer ${ }^{22)}$, and loaded onto second-dimension gels. Separated proteins were visualized by Coomassie Blue staining or autoradiography at room temperature for seven days.

Western blotting. Separated proteins were transferred electrophoretically to nitrocellulose membranes $(0.45 \mu \mathrm{m}$, Toyo Roshi Co., Ltd.). The membranes were immersed in the blocking solution containing $20 \mathrm{mM}$ Tris- $\mathrm{HCl}(\mathrm{pH} 7.5), 0.5 \mathrm{M} \mathrm{NaCl}$ and $3 \%$ gelatin for $1 \mathrm{hr}$ at room temperature and then washed twice in TBST (20 mM Tris- $\mathrm{HCl}(\mathrm{pH} 7.5), 0.5 \mathrm{M} \mathrm{NaCl}$ and $0.05 \%$ Tween 20) for 5 min. The membranes were then incubated with BGMV antiserum, washed in TBST, incubated with antibodies conjugated with horseradish peroxidase (Immuno-blot assay kit, Bio-Rad Co., Ltd.), and finally immersed in the development solution according to the manufacturer's directions ${ }^{3)}$. 
A

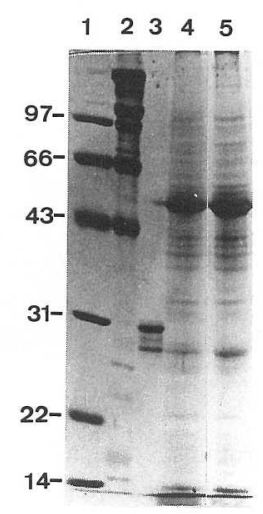

B

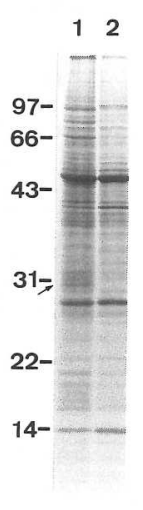

C

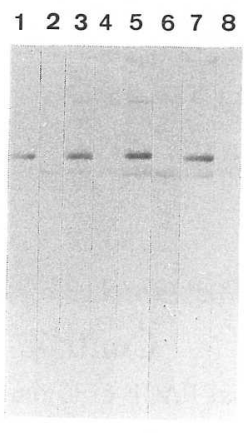

Fig. 1. SDS-PAGE of leaf proteins. (A) Proteins were stained with Coomassie Blue. Lanes: 1 and 2, molecular weight markers; 3 , purified BGMV coat protein $(3 \mu \mathrm{g})$; 4, proteins extracted from leaves 6 days after BGMV infection ( $50 \mu \mathrm{g}) ; 5$, proteins extracted from mock- infected leaves 6 days after infection (50 $\mu \mathrm{g})$. (B) Autoradiograms of in vivo radiolabeled leaf proteins. Lanes: 1, at 6 days after BGMV infection; 2, mock-infected. Each lane was loaded with $1 \times 10^{4} \mathrm{cpm}$, and the gel exposed for eight weeks. (C) Analysis of BGMV coat protein by Western blotting. Leaf proteins $(50 \mu \mathrm{g})$ were probed with antiserum to BGMV virions. Lanes: 1, 3, 5 and 7, proteins from BGMV-infected leaves; 2, 4, 6 and 8 , proteins from mock-infected leaves; 1 and 2, at 6 days after infection; 3 and 4, at 9 days after infection; 5 and 6 , at 12 days after infection; 7 and 8 , at 15 days after infection.

\section{RESULTS}

\section{Comparison of protein patterns between BGMV- and mock-infected leaves by one- dimensional PAGE}

We compared protein profiles by one-dimensional PAGE. When stained with Coomassie Blue, no difference was found between BGMV-infected (Fig. 1A lane 4) and mock-infected (Fig. 1A lane 5) leaves. Next, we compared the autoradiographs of $\left[{ }^{35} \mathrm{~S}\right]$ methionine-incorporated proteins of BGMV-infected (Fig. 1B lane 1) and mock-infected (Fig. 1B lane 2) leaves, however, a $30 \mathrm{kDa}$ protein was detected only in BGMV-infected leaves (indicated by an arrow in Fig. 1B), while the other protein bands were identical. This $30 \mathrm{kDa}$ protein band was found to migrate to the same position as the coat protein band from the purified virus (Fig. $1 \mathrm{~A}$ lane 3 , and $1 \mathrm{~B}$ lane 1 ).

To confirm that this $30 \mathrm{kDa}$ protein is the coat protein of BGMV, Western blot analysis was performed. Total proteins were extracted from the first trifoliolated leaves after 6, 9, 12 and 15 days following infection. Coomassie Blue staining revealed no differences in the electrophoretic profiles, for the different days after infection (data not shown). Fig. 1C shows the results of Western blot analysis of these proteins. The coat protein of BGMV was detected only in infected leaves (lanes 1, 3, 5 and 7), and not in mock-infected leaves (lanes 2, 4, 6 and 8). The amount of expressed coat protein increased within 6 days after infection, reached a maximum at 12 days after infection, but decreased slightly at 15 days. In all lanes, we could detect weak bands just below the coat protein band. Although the antibody employed in these experiments was prepared using a highly-purified virus particle as antigen ${ }^{13}$, these weak bands, especially those in Fig. 1A lane 3, could not be eliminated. These bands reacted to non-specific antibodies in a Western blotting experiments (Fig. 1C).

\section{Comparison of protein profiles between BGMV- and mock-infected leaves by two- dimensional PAGE}

Since no differences between BGMV- and mock-infected protein profiles, except for the coat protein band, could be identified using one-dimensional PAGE, protein profiles were further examined by two-dimensional $\mathrm{PAGE}^{22}$. For the first dimension, a non-equilibrium $\mathrm{pH}$ gradient was used according to the method by O'Farrell et al. ${ }^{23)}$, as this gel system demonstrated a better resolution than an equilibrium 


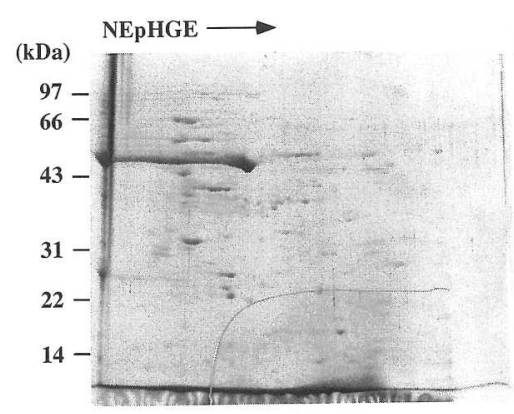

Control

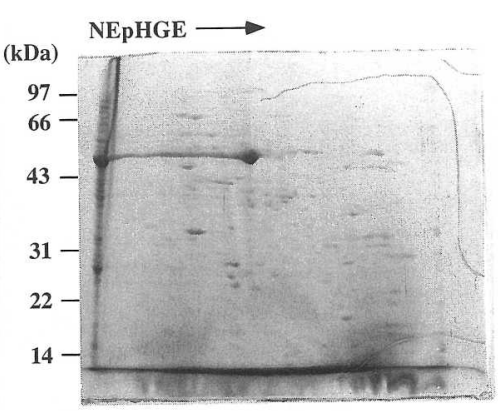

6 Days

Fig. 2. Two-dimensional PAGE of Coomassie Blue stained leaf proteins 6 days after infection. Left panel, proteins $(200 \mu \mathrm{g})$ from mock-infected leaves (control); right panel, proteins (200 $\mu \mathrm{g})$ from BGMVinfected leaves. The molecular weight markers are as indicated $\left(\mathrm{Mr} \times 10^{-3}\right)$; phosphorylase b (97), BSA (66), ovalbumin (43), carbonic anhydrase (31), soybean trypsin inhibitor (22) and lysozyme (14).

pH gel electrophoresis system (data not shown). Fig. 2 shows the Coomassie Blue stained protein profiles of BGMV-infected leaves (right panel) and mock-infected leaves (control, left panel) 6 days after infection. More than 100 spots were observed in both control and infected-leaf samples, however, no differences were found between these two protein profiles. The most prominent spot, at about $53 \mathrm{kDa}$ of the neutral $\mathrm{pH}$ region, was the ribulose-1,5-bisphosphate carboxylase/oxygenase (RuBisCO) large subunit. When the two-dimensional protein profiles of leaves were compared at 9, 12 or 15 days after infection, there were also no differences between BGMV- and mock-infected plants (data not shown). As the coat protein did not enter the first-dimension gel, it could not be identified on the two-dimensional gel pattern (data not shown).

To compare the expression pattern of de novo synthesized proteins after virus infection, leaf proteins were labeled with $\left[{ }^{35} \mathrm{~S}\right]$ methionine. The efficiency of isotope incorporation into control leaves was almost equivalent at all sampling days after mock-infection. However, isotope incorporation into BGMV-infected plants was reduced to about $50 \%$ of the control level at 6,9 , and 12 days after infection, and to ca. $20 \%$ of the control at 15 days. These results suggest that the level of protein synthesis in the host plant reduces with the progress of virus infection. Fig. 3 shows the profiles of two-dimensional PAGE of the labeled proteins, in which over 500 spots were identified. The first row of Fig. 3 shows the autoradiograms of labeled proteins extracted from leaves at 6 days after mock and BGMV infection. These two autoradiograms were very similar, but only one spot could be identified, which was specifically induced in the BGMV-infected leaves (open arrow-head). This polypeptide was a neutral protein of $24 \mathrm{kDa}$ and its level of synthesis/expression was reduced with the passage of time after infection. At 12 days after infection (Fig. 3 third row, right panel), the protein spot was weak, and at 15 days (lowest right panel of Fig. 3) it was even weaker. This $24 \mathrm{kDa}$ protein could be consistently induced in our experiments. There was no correspondence in size between this $24 \mathrm{kDa}$ protein and the deduced open reading frames of the BGMV sequence ${ }^{11,19)}$, and therefore we assume that it is encoded on the plant genome. Other protein spots of controls and infected leaves were all of the same intensity, except for the large subunit of ribulose-1,5-bisphosphate carboxylase/oxygenase which decreased at the late infection stage (12 and 15 days after infection) compared to the respective controls.

\section{DISCUSSION}

Comparison in protein profiles between BGMV- and mock-infected leaves showed that two specific polypeptides were induced by virus infection. One was the coat protein of BGMV, the other was a 24 $\mathrm{kDa}$ protein. Even employing the high-resolving two-dimensional PAGE with in vivo labeling method, we could not detect changes in most of the protein spots.

From our present results, the coat protein was the only detected protein encoded by the BGMV 


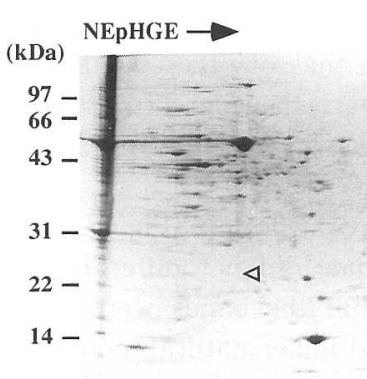

6 Days Control

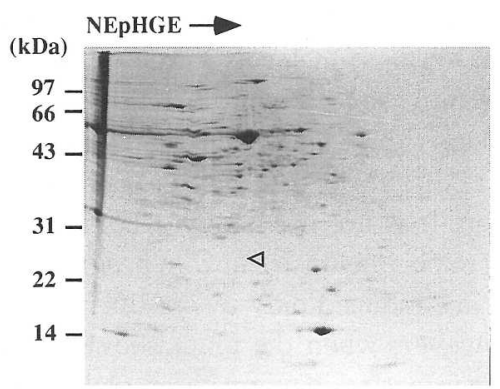

9 Days Control

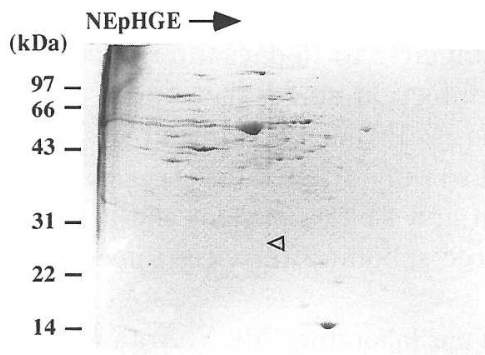

12 Days Control

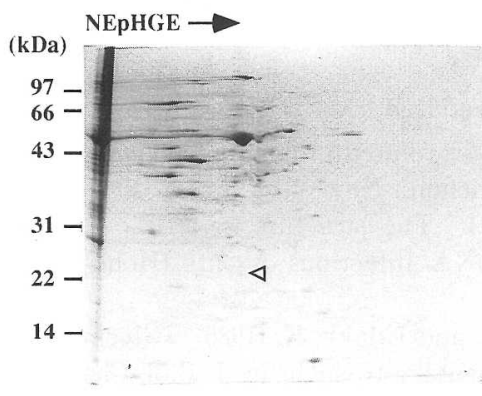

15 Days Control

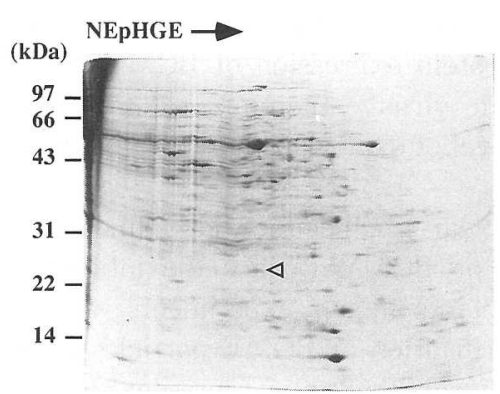

6 Days BGMV infected

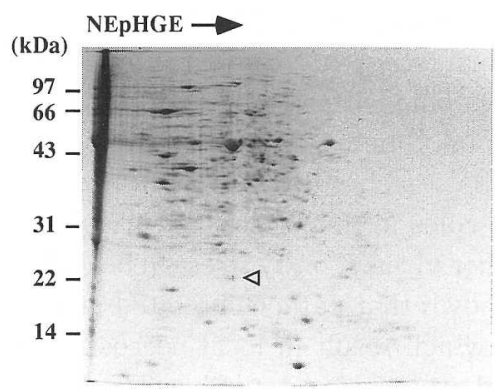

9 Days BGMV infected

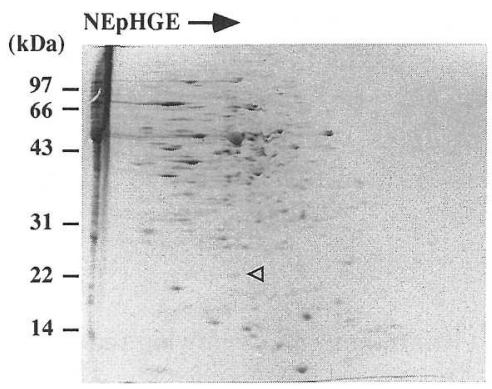

12 Days BGMV infected

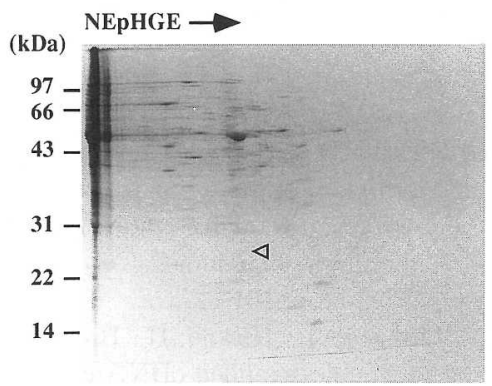

15 Days BGMV infected

Fig. 3. Autoradiograms of in vivo labeled leaf proteins during BGMV or mock-infection. Left column; proteins from mock-infected leaves (control), right column; proteins from BGMV-infected leaves. The number of days indicates the period after infection. Each panel was loaded with $1 \times 10^{5} \mathrm{cpm}$, and the gels exposed for seven days. Arrowhead indicates the position of $24 \mathrm{kDa}$ protein.

genome. We have found that DNA 2 encodes a functional protein of systemic infection (Aosaki and Ikegami, in preparation), and Rogers et al ${ }^{24)}$ have found that tomato golden mosaic virus also encodes the same functional proteins on DNA 2. Such proteins should be expressed specifically in the infected 
leaves, however, possibly because of the low levels of gene expression, we could not detect them. The level of coat protein expression of BGMV was lower than that of other plant viruses, such as the cucumber mosaic virus ${ }^{26}$, therefore we were unable to detect the coat protein by Coomassie Blue staining. Low level of expression may also be the major reason why we could not detect other viral gene products.

It was not clear whether the weak bands just below the coat protein (Fig. 1C) originated from the host plant cell or $\mathrm{BGMV}^{4)}$. Since the intensity of the bands did not differ between BGMV- and mock-infected plants in our experiments, we considered that the bands were of host-plant origin. Because the purification of BGMV particles were performed under natural, non-denatured condition, therefore, these weak bands may represent host plant-originated proteins attached to the virus particles. We suspect that this virus-associated protein is related to the process of virus infection.

The $24 \mathrm{kDa}$ protein, induced by BGMV infection was most highly expressed at 6 days after virus infection (the early stage of virus infection), but its expression level decreased with the progress of infection (Fig. 3). This pattern of expression was in contrast to the pattern of coat protein expression, which reached a maximum level at 12 days (Fig. 1). This time was found to correspond to the time when the titer of BGMV reaches its maximum leve ${ }^{25}$. We, therefore, assume that this $24 \mathrm{kDa}$ protein plays some important roles in the process of virus infection. It is not yet known whether the $24 \mathrm{kDa}$ protein is induced by other viruses, or by stress in bean. Such experiments are now in progress in our laboratory.

It is well known that pathogen-related proteins are induced only by specific combinations of virus and host plant, which result in local necrosis ${ }^{28}$. However, when the plant shows systemic symptoms, pathogen-related proteins are not induced by the virus infection in many cases. Only the coat protein and $24 \mathrm{kDa}$ protein were induced by BGMV infection when exmained in our two-dimensional gel system. Prior to this study, we postulated that there would be many differences at the protein level when mosaic symptoms were clearly visible in the late-infection stage (12 to 15 days after infection). As the color of the mosaic plant parts turns yellowish at the late-infection stage, there must be some quantitative changes in the proteins which perform photosynthesis. In our experiment, we did not separate the mosaic parts from the healthy vegetative parts, and so only a few differences could be detected in the protein profiles, such as appearance of coat protein and $24 \mathrm{kDa}$ protein and a slight decrease in the ribulose-1,5-bisphosphate carboxylase/oxygenase large subunit after virus infection (Fig. 3).

The authors wish to thank the following members of our laboratory; Mr. Y. Arita for use of purified BGMV proteins; Mrs. A. Murayama for introducing us to Western blotting and Mr. S. Shimizu for the antiserum to BGMV virions. We thank Dr. S. Youssefian (Akita Prefectural College of Agriculture, Japan), Drs. T. Kayano and I. Havukkala (National Institute on Agrobiological Resources, Japan) for careful criticism of the manuscript.

\section{Literature cited}

1. Carr, J.P. and Klessig, D.F. (1989). The pathogenesis-related proteins of plants. In Genetic Engineering, Principles and Methods (Setlow, J. eds.). Vol. 11, Plenum, New York. pp. 65-100.

2. Davies, J.W., Townsend, R. and Stanley, J. (1987). The structure, expression, functions and possible exploitation of geminivirus genomes. In Plant DNA Infectious Agents (Hohn T. and Shell, J. eds.). Springer-Verlag, Vienna. pp. 31-52.

3. Fukazawa, C., Momma, T., Hirano, H., Harada, K. and Udaka, K. (1985). Glycinin $\mathrm{A}_{3} \mathrm{~B}_{4} \mathrm{mRNA}$ cloning and sequencing of double-stranded cDNA complementary to soybean. J. Biol. Chem. 260:6234-6239.

4. Goodman, R.M., Shock, T.L., Browning, K.S. and Bowers, G.R., Jr. (1980). The composition of bean golden mosaic virus and single stranded DNA genome. Virology 106 : 168-172.

5. Guy, C.L., Hummel, R.L. and Haskell, D. (1987). Induction of freezing tolerance in spinach during cold acclimation. Plant Physiol. $84:$ 868-871.

6. Guy, C.L. and Haskell, D. (1988). Detection of polypeptides associated with the cold acclimation process in spinach. Electrophoresis $9: 787-796$.

7. Harber, S., Howarth, A.J. and Goodman, R.M. (1983). Restriction map and Southern analysis of the bean golden mosaic virus genome. Virology 129 : 469-473.

8. Harber, S., Ikegami, M., Bajet, N.B. and Goodman, R.M. (1981). Evidence for a divided genome in bean 
golden mosaic virus, a geminivirus. Nature $289: 324-326$.

9. Hanley-Bowdoin, L., Elmer, J.S. and Rogers, S.G. (1989). Functional expression of the leftward open reading frames of the A component of tomato golden mosaic virus in transgenic tobacco plants. Plant Cell $1: 1057-1067$.

10. Hanley-Bowdoin, L., Elmer, J.S. and Rogers, S.G. (1990). Expression of functional replication protein from tomato golden mosaic virus in transgenic tobacco plants. Proc. Natl. Acad. Sci. USA 87 : 1446-1450.

11. Howarth, A.J., Caton, J., Bossert, M. and Goodman, R.M. (1985). Nucleotide sequence of bean golden mosaic virus and a model for gene regulation in geminiviruses. Proc. Natl. Acad. Sci. USA 82 : 3572-3576.

12. Ikegami, M., Harber, S., Bajet, N.B. and Goodman, R.M. (1981). Isolation and characterization of virusspecific double-stranded DNA from tissue infected by bean golden mosaic virus. Proc. Natl. Acad. Sci. USA $78: 4102-4106$.

13. Ikegami, M. and Shimizu, S. (1988). Serological studies on mung bean yellow mosaic virus. J. Phytopathol. $122: 108-112$.

14. Laemmli, U.K. (1970). Cleavage of structural proteins during the assembly of the head of bacteriophage T4. Nature $227: 680-685$.

15. Lazarowitz, S.G. (1987). The molecular characterization of geminivirus. Plant Mol. Biol. Rep. 4: 177-192.

16. Lowry, O.H., Rosebrough, N.J. Farr, A.L. and Randall, R.J. (1951). Protein measurement with the Folin phenol reagent. J. Biol. Chem. $193: 265-275$.

17. Matthews, R.E.F. (1981). Plant Virology (2nd ed.). Academic Press, London/New York. p. 897.

18. Morinaga, T., Ikegami, M. and Miura, K. (1983). Infectivity of the cloned DNAs from multiple genomic components of bean golden mosaic virus. Proc. Japan Acad. 59, series B : 363-366.

19. Morinaga, T., Ikegami, M., Shimotohno, K. and Miura, K. (1987). Total nucleotide sequences of the infectious cloned DNAs of bean golden mosaic virus DNA. Microbiol. Immunol. 31: 147-154.

20. Morinaga, T., Ikegami, M., Arai, T., Yazaki, K. and Miura, K. (1988). Infectivity of cloned tandem dimer DNAs of bean golden mosaic virus. J. gen. Virol. 69: 897-902.

21. Murayama, A., Yamaya, Y. and Ikegami, M. (1991). Identification of the coat protein gene of bean golden mosaic geminivirus. Intervirology $32: 258-261$.

22. O'Farrell, P.H. (1975). High resolution two-dimensional electrophoresis of proteins. J. Biol. Chem. 250 : 4007-4021.

23. O'Farrell, P.Z., Goodman, H.M. and O'Farrell, P.H. (1977). High resolution two-dimensional electrophoresis of basic as well as acidic proteins. Cell 12 : 1133-1142.

24. Rogers, S.G., Bisaro, D.M., Horsch, R.B., Fraley, R.T., Hoffman, N.L., Brand, L., Elmer, J.S. and Lloyd, A. M. (1986). Tomato golden mosaic virus A component DNA replicates autonomously in transgenic plants. Cell $45:$ 593-600.

25. Shock, T.L. and Goodman, R.M. (1981). Time-course studies on virus titer and DNA component ratio in beans infected with bean golden mosaic virus. Phytopathology $71: 80-82$.

26. Takahashi, T., Ehara, Y. and Hirano, H. (1991). A protein in the oxygen-evolving complex in the chloroplast is associated with symptom expression on tobacco leaves infected with cucumber mosaic virus strain Y. Plant Mol. Biol. 16 : 689-698.

27. Van Loon, L.C. (1985). Pathogenesis-related proteins. Plant Mol. Biol. 4 : 111-116.

28. Van Loon, L.C. (1989). Stress proteins in infected plants. In Plant-Microbe Interaction. Molecular and Genetic Perspectives (Kosuge, T. and Nester E.W. eds.). Vol. 3, McGraw Hill, New York. pp. 198-237.

和 文 摘 要

番 保徳・坂西 昌則・池上 正人：Phaseolus vulgarisでのBean golden mosaic virus感染特異的タンパク質の検 出

Bean golden mosaic virus (BGMV)が宿主インゲン(Phaseolus vulgaris)へ感染する際のタンパク質パターンの変 化をポリアクリルアミドゲル電気泳動を用いて解析した。コマジーブルー染色による比較では 1 次元および 2 次元ゲ

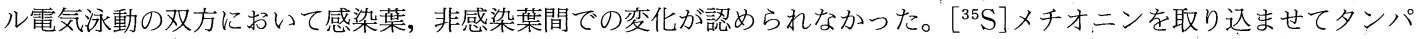
ク質パターンを比較するとウイルス感染に特異的なバンドが 2 つ検出された。一方はBGMVの外皮夕ンパク質であ り, 他方は宿主植物由来と推定される $24 \mathrm{kDa}$ タンパク質であった。ウイルス感染の進行過程のなかで, ウイルス外皮 タンパク質は感染後期で強く発現しており,一方 $24 \mathrm{kDa}$ タンパク質は感染初期で強く発現していた。この $24 \mathrm{kDa}$ タン パク質はウイルスの感染成立に際し重要な役割を担うことが示唆された。 